\title{
Parotidectomía y vena facial
}

\section{Parotidectomy and facial vein}

\section{F. Hernández Altemir ${ }^{1}$, S. Hernández Montero², S. Hernández Montero³, E. Hernández Montero ${ }^{4}$}

Resumen: La cirugía de los tumores benignos de la parótida, es una cirugía de relaciones con estructuras fundamentalmente nerviosas cuyo daño, representa un gravísimo problema psicosomático por definirlo de una manera genérica. Para ayudar al manejo quirúrgico del nervio facial periférico, es por lo que en el presente artículo tratamos de enfatizar la importancia de la vena facial en la disección y conservación del nervio, precisamente donde su disección suele ser más comprometida, esto es en las ramas más caudales. El trabajo que vamos a desarrollar hay que verlo pues, como un ensalzamiento de las estructuras venosas en el seguimiento y control del nervio facial periférico y de porqué no, el nervio auricular mayor no siempre suficientemente valorado en la cirugía de la parótida al perder protagonismo con el facial.

Palabras clave: Facial; Nervio facial; Nervio auricular mayor; Vena facial

Aceptado: 25.08.2009

1 Licenciado Médico Estomatólogo y Médico Especialista en Cirugía Oral y Maxilofacial. Miembro Fundador de la Sociedad Europea de Cirugía Cráneo-Maxilofacial. Académico Correspondiente de la Real Academia de Medicina de Zaragoza. España

2 Dra. en Medicina y Cirugía y Licenciada Médico Odontólogo y Médico Especialista en Cirugía Oral y Maxilofacial. Directora Academia del Master Oficial de Implantología Dental y Prótesis Implantosoportada de la Universidad Alfonso X el Sabio de Madrid.

3 Licenciada en Medicina y Cirugía, Médico Odontólogo. Profesora de Patología Bucal de la Licenciatura de Odontología de la Facultad de Ciencias de la Salud y del Deporte (Huesca) en la Universidad de Zaragoza. España

4 Facultativo Médico Especialista en Otorrinolaringología del Hospital de Viladecans y del Instituto de Neuro-Otología García Ibáñez de Barcelona. España

\section{Correspondencia:}

Dr. F. Hernández Altemir

Web: www.headandneck.es

Email: drhernandezaltemir@yahoo.es

\begin{abstract}
Benign parotid tumor surgery is related to fundamental nervous structures, defined simply: that when damaged cause great psychosomatic problems. In order to make peripheral facial nerve surgery easy to handle for the surgeon this article emphasizes the importance of the facial vein in the dissection and conservation of the nerve. Its dissection can be compromised if the caudal branches are damaged. The study that we develop should be seen as praise for the vein structures in the follow up and control of the peripheral facial nerve, and the main auricular nerve that is often undervalued when it is no longer the protagonist in the face.
\end{abstract}

Key words: Facial; Facial nerve; Great auricular nerve; facial vein 


\section{Introducción}

Siempre nos ha sorprendido en la cirugía convencional de la parótida, el beneficio quirúrgico que significa además claro es de conservar el nervio facial al límite, el conservar de la misma manera, el nervio auricular mayor, la yugular externa y extender su disección hacia la región cefálica, la comunicante intraparotídea y la vena facial y ver y sentir la relación de la misma sobre prácticamente todas las ramas periféricas del nervio facial, creándose un plano ideal para la disección del mismo y facilitar de la misma manera, la exéresis con seguridad de todo el contenido supuestamente patológico de la glándula.

\section{Material y método}

El que hemos obtenido a lo largo de más de cuarenta años de nuestra práctica médico quirúrgica en el estudio y tratamiento de la patología de las glándulas salivares.

Siempre se ha dicho, que la cirugía de la parótida es la cirugía del nervio facial por las gravísimas secuelas que su lesión parcial o total puede ocasionar y por ello, a lo que más énfasis se ha dado en la misma, es al reconocimiento, seguimiento control y conservación del nervio periférico por excelencia, desde su salida troncal en la profundidad del valle construido por el digástrico y el desfiladero del conducto auditivo externo y en principio, sin duda, esta parece la más habitual de las maneras y el mejor y más seguro procedimiento para su control.

En esta cirugía, siempre se habla de alguna forma de "maniobras o puntos anatómicos clave" para buscar y encontrar primero y seguir segundo, el tronco nervioso del facial a su salida del agujero estilomastoideo y facilitar el seguimiento y disección de sus ramas.

Nosotros vamos a pretender enfatizar más, en lo quizá más descuidado y algo olvidado de la cirugía de la glándula, nos referimos al control y disección del nervio auricular mayor en todas o en parte de sus ramas y sobre todo, al sistema venoso caudal a la parótida, formado por la yugular externa, la comunicante intraparotídea y la vena facial y hay que decir ya, que quizá parece pueda tener y no con cierta razón para los menos habituados, menor entidad

Figura 1. Preoperatorio inmediato.

Figure 1. Immediate preoperation.

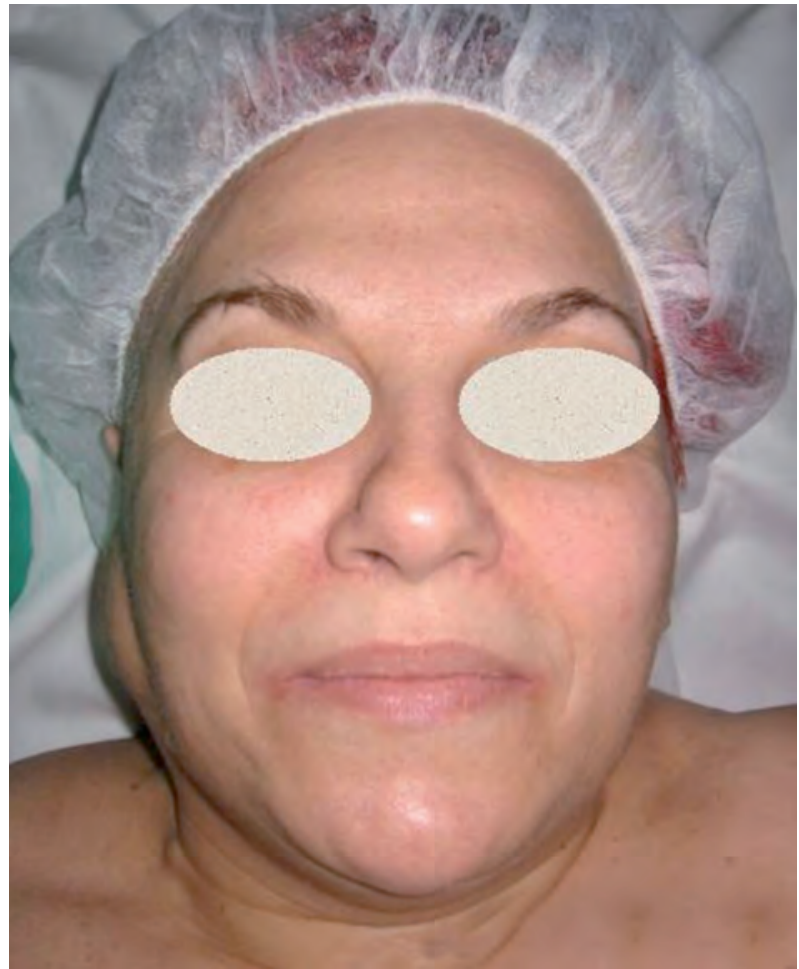

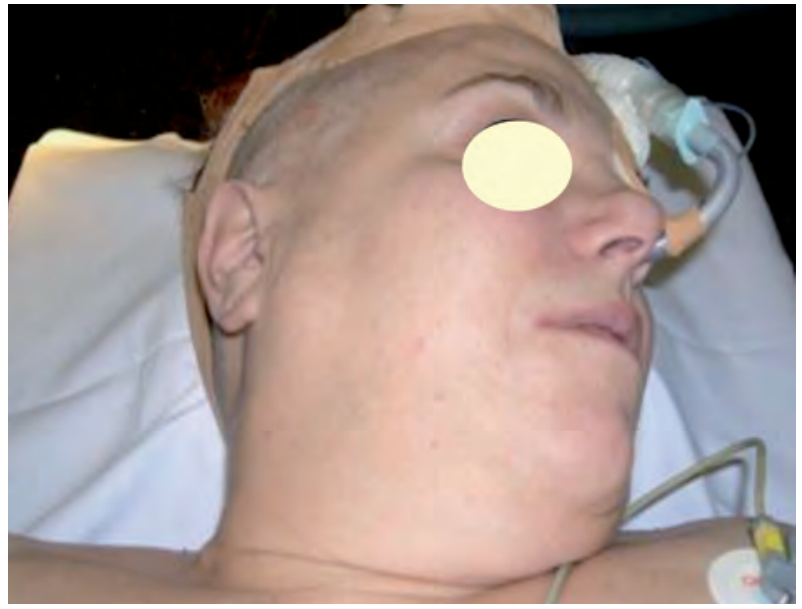

Figura 2. Intubación nasotraqueal contralateral con fijación nasal convencional y pericraneal (Hernández Altemir, 1986) del tubo traqueal.

Figure 2. Nasotrachial contra lateral tubation, conventional nasal fixation and tracheal tube is precranial (Hernandez Altemir, 1986).

\section{Materials and Methods}

The one we have obtained over the more than forty years that our Medical Surgery Practice has been around studying the treatment of pathologies of the salivary glands.

They have always said that the parotid surgery is the best procedure to avoid the severe effects of partial or total lesion of the facial nerve. It has been emphasized that conservation of the peripheral nerve from its main exit to the deep valley built by the digastriacus and the gorge of the external auditory duct. At first, this appears without a doubt the most common of ways and the best and most secure procedure for its control.

Maneuvers and key anatomic points are always discussed in reference to this surgery. These maneuvers are intended to first find and then follow the main facial nerve at its mastoid style hole and allow the follow-up and dissection of its branches.

We are going to try to emphasize what is perhaps the most neglected and forgotten aspect of the gland surgery. 
anatómica que los puntos mas esenciales que arriba señalábamos.

El punto clave venoso, es conocido, practicado y referenciado entre otros por Conley 1961, 1,2 1973 J.J. Redon H. ${ }^{3} 1972$, L.M. Gil-Carcedo 1992.4

Todo pues con la intención de apoyar una posible "nueva filosofía", no sólo quirúrgica, sino conceptual, para intentar mejorar aún más, entre otros el abordaje y disección, sobre todo de las inestables ramas faciales inferiores, en la porción más caudal del facial y de la parótida.

La cirugía de la parótida donde verdaderamente empieza casi siempre es en el manido valle del digástrico (punto clave por excelencia), formado además de por éste en su unión mastoidea, por el cartílago del pabellón, en su cara externa y en la zona inferior y anterior del conducto auditivo externo, donde emite una prolongación o proyección, que señala, como un puntero la salida del nervio, 1,2 a nivel como no, mastoideo anterior junto con el tercio cervical anterior del músculo esternocleidomastoideo, que es, además de músculo principal en la anatomía radical y sobre todo funcional de la cirugía del cuello.

Hace años la cirugía de la parótida, la empezaba Ramón Castillo Escandón ${ }^{5,6}$ y otros, buscando en la periferia el marginal, técnica retrógrada, que compara hoy día en su frecuencia con la anterograda ${ }^{7}$ acercándose al nervio de rodillas, ${ }^{3}$ aunque otra vez Castillo, 5,6 decía que él lo hacía arrastrándose (yo creo que pese a los adelantos, seguimos más o menos muchos de nosotros con la misma actitud), antes, por temor sobre todo, de dejar al paciente con el labio torcido y por nuestro propio prestigio, pero ahora además, por connotaciones judiciales que no vienen al caso desarrollar.

Volviendo a nuestro valle, de donde casi nunca deberíamos apartarnos, es ahí, el lugar donde no pocas veces hacemos un falso gesto de autoridad y firmeza hincando, con seguridad relajante, al inicio de esta cirugía, marcando con nuestros dedos índices disfrazados de "flechas romas", un vértice lleno de incertidumbre no obstante, en el lugar donde quisiéramos que estuviera el tronco, con la esperanza de casi acariciarlo para descubrirlo, controlarlo y todo para hacer el seguimiento de sus ramas, situadas un poco por delante de ese abismo anatómico, hasta que sobrepasan la superficie maseterina, para caer en una cascada contenida, y hacerse nuevamente

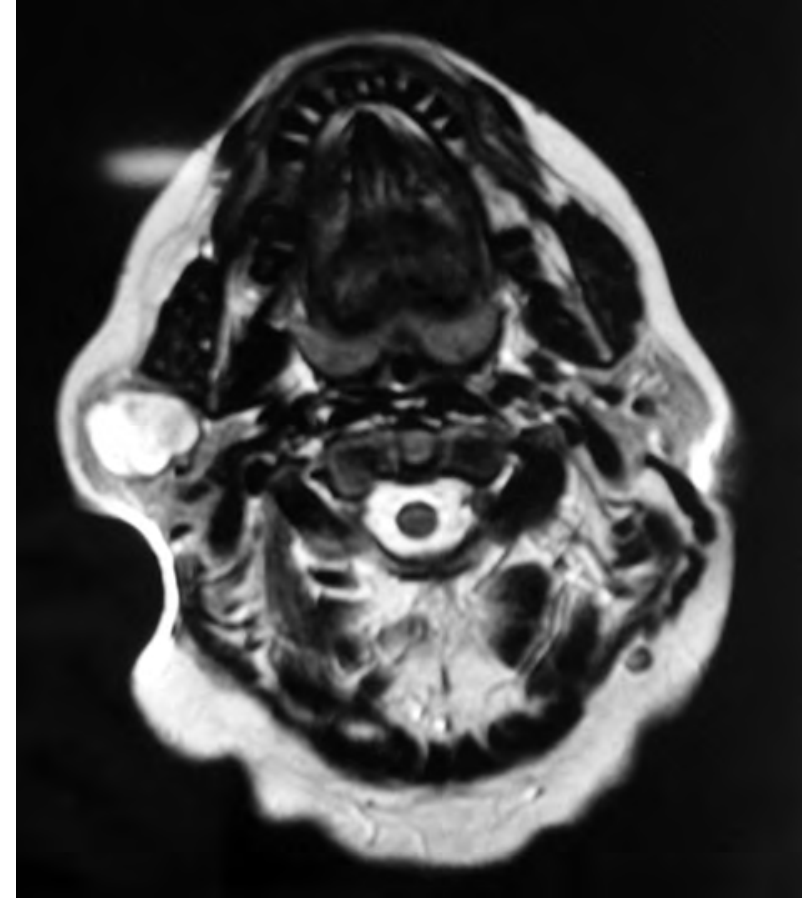

Figura 3. Un corte contrastado de la RM, demostrativo de la patología parotídea derecha.

Figure 3. Contrasted cut of MRI, showing the left parotid pathology.

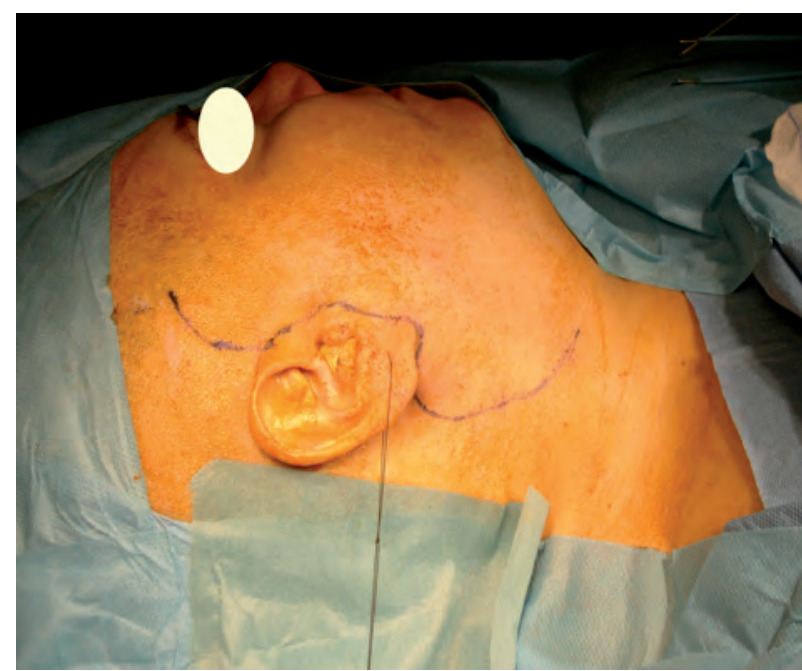

Figura 4. Posicionamiento latero-cervico-facial izquierdo y diseño de la incisión.

Figure 4. Left lateral cervical facial positioning and incision design.
We refer to the control and dissection of the main auricular nerve in all or part of the branches, and above all the caudal vein system of the parotid. This is formed by the external jugular, the connecting intra parotid and the facial vein. It must be mentioned that maybe it seems that it could have, for no apparent reason, lower anatomic entity than the most essential points that we already indicated.

The key point is known, practiced referenced among others by Conley 1961,1,2 1973,3 J.J. Redon H. ${ }^{3}$ 1972, L. M. Gil-Carcedo 1992. ${ }^{4}$ All of which is intended to support a possible "new philosophy", not only a surgical one but also a conceptual one. In an effort to improve the approach and dissection and above all, the weak inferior face branches in the most caudal of the ace and parotid.

The parotid surgery usually starts in the digastricus valley (key point for excellence), made up of not only this but also its mastoid union, by the auricular cartilage, in its external face and in the inferior and anterior zone of the external ear, where it transmits a prolonged and projected signal, similar to an indicator of the nerve exit (1 and 2) Conley 1961 and 1973). In reference to the anterior mastoid next to the third cervical anterior of the sternocleidomastoid muscle, that is not only the principal muscle in the radical anatomy but also functional in the neck surgery.

Years ago parotid surgery was started by Ramon Castillo Escandón and others who were looking for the peripheral margin, reactionary technique that today is compared to the frequency of anterograde7 (Barry O'Regan, 2008). Coming close to the knee nerve ${ }^{3}$ (Redon 1972) although again, 5,6 Castillo said that he did it dragging himself along (I think 
enigmático en su recorrido y digo así, porque remedan, cómo lo hacen algunos sorprendentes ríos del andalus español, donde eso sí, es muy funcional en la proximidad y profundidad manifiesta del pliegue incuestionablemente individual y cambiante nasogeniano, a veces dependiente en su diseño de avatares o emociones individuales más o menos cronificadas del paciente.

Obviamos referirnos con tanta sensibilidad, en esta descripción quizá un tanto onírica, sin con ello quitarles ninguna importancia, como se puede comprender, por su importantísima labor funcional, a las ramas faciales superiores, sin duda de mas contundente y noble presencia anatómica, en su camino frontoorbitario y por lo tanto menos vulnerables a nuestras posibles impertinencias quirúrgicas, sin con ello dejar claro que nos merecen, cómo no, todo nuestra atención y respeto, pues van a tener connotaciones funcionales sobresalientes sobre todo en la función fronto palpebral.

Pero hay que enfatizar además de lo dicho, de la importancia que para nosotros tiene pues para la disección, seguimiento y respeto del facial, y cómo otro gran punto clave, el reconocimiento y también disección y por lo tanto conservación de la azulada, caudalosa y casi vertical guirnalda venosa (yugular externa, comunicante intraparotídea y vena facial) entendida así, al considerar el decúbito del paciente y la lateralización del campo quirúrgico como se puede observar en la iconografía del caso clínico adjunto (Figs. 1 a 9) y sobre todo, en la figura 6.

Guirnalda, que está formada, insistimos fundamentalmente, por la porción cervical alta de las vena yugular externa, la comunicante aludida y sobre todo, de la vena facial, ambas inmediatamente por debajo ya, de la porción medial de las ahora sí, inestables ramas faciales cervicomarginales, donde se hecha casi siempre de menos, algo más de anatomía (grosor) diseño, morfología, estabilidad y en definitiva personalidad quirúrgica y que actúa como suspendiéndolas y meciéndolas, a la vez que dividiendo etc., su trayecto periférico, en una parte funcional anterior a ese azulado eje venoso, que lleva al enigmático valle nasogeniano, donde las queremos perder con toda la intención en la cirugía y sabiendo que vienen, de otra región más posterior, inerte y "afuncional", fundamentalmente conductual, desde su punto de nacimiento periférico está un poco más allá del vértice cervicomastoideo del digástrico, a un través aproximado de dedo, por encima del mismo, es

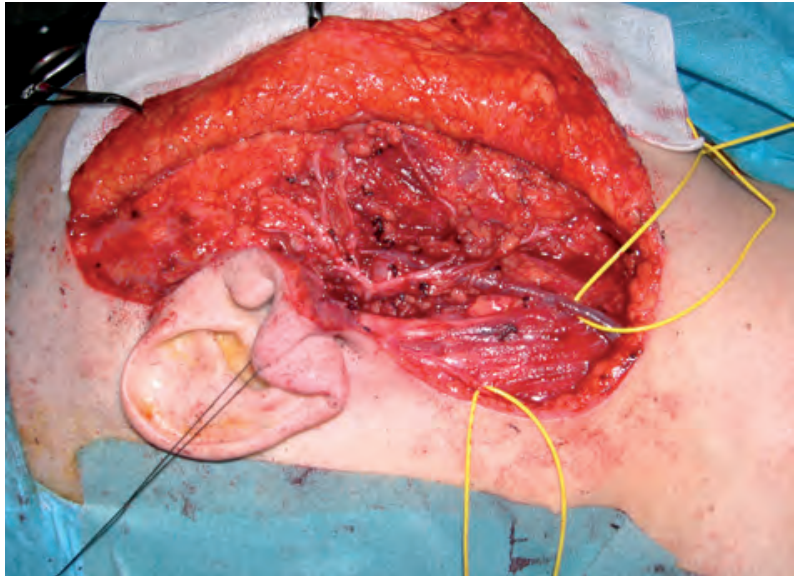

Figura 5. El seguimiento de la vena facial ayuda a la disección, seguimiento y control de las ramas periféricas caudales del ner-

Figure 5. Following the facial vein helps dissection, follow up and control of the caudal peripheral branches of the facial nerve.

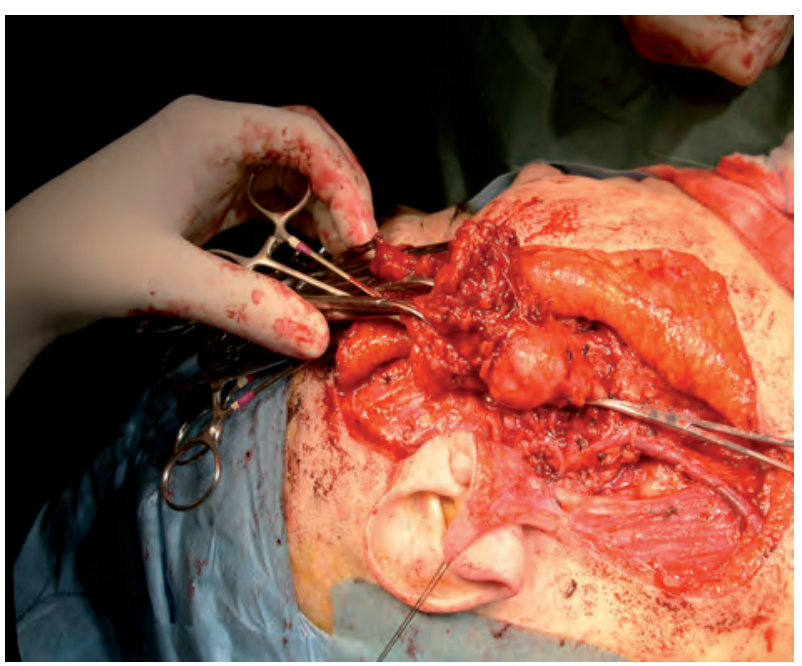

Figura 6. Aspecto intraoperatorio y momento de la disección y conservación de la continuidad de la vena facial objeto fundamental de este artículo y del nervio auricular mayor.

Figure 6. Intra operative aspect and dissection, conservations of the nerve. that despite everything many of us continue to have the same attitude) out of fear of leaving the patient with a crooked lip and because of our own prestige, but even more now because of our judicial connotations that are not relevant to development.

Returning to our valley, from which we should almost never separate ourselves, the place where we often make an incorrect gesture of authority, leaving out with relaxed certainty at the beginning of surgery, noting with our index fingers the vertex filled with uncertainty. We do this where we hoped the trunk would be, with hope of almost touching it to discover it, control it and everything to follow the branches that are situated just before the anatomic abyss, until they pass over the maseter surface in order to fall in a contained cascade and make its route enigmatic again. It imitates some surprising rivers in Andalucía Spain where it is more functional in proximity and depth that comes from the unquestionable individual creases and changing nosogenesis. Sometimes it depends on its vicissitude designs or individual emotions more or less chronified by the patient.

Obviously we, with sensitivity, refer, in this description perhaps too dreamlike, without removing their importance, because of its very important labor function, the superior facial branches, without a doubt of more convincing and noble anatomic presence in its frontal orbit path and because of this it is more vulnerable to our impertinent surgical possibilities. It is obvious that they deserve all of our attention and respect because they are going to have excellent functional connotations, especially in the frontal palpebral.

But we must emphasize that apart from what we said, dissection, follow-up and facial respect. Another big key is the recognition, dissection and preservation of the bluish, rich, abundant and almost vertical venous garland (exter- 
decir, donde el tronco se divide en las diferentes ramas.

Nos vamos a afanar pues, en difundir este concepto venoso, en nuestra experiencia en la cirugía de la glándula y de su patología, con la intención de facilitar el reconocimiento, trayecto, disección y conservación, de quizá el nervio cuya posible lesión, supone daños no sólo funcionales evidentes y conocidos, sino los que podríamos denominar como venimos diciendo secuelas psicosomáticas de las que todos los cirujanos de la zona somos conocedores, muchas veces impredecibles y además, como ayuda incuestionable para la correcta ablación de la patología adjunta a la parótida.

El cirujano de cuello, es fundamentalmente un cirujano de venas (desde hace años más conservadas por la aparición de las técnicas reconstructivas microquirúrgicas) y aponeurosis y esto si se reconoce y se práctica desde Crile 1905, ${ }^{8}$ Hayes Martin 1951, ${ }^{9}$ Oswaldo Suárez 1963, ${ }^{10}$ Hernández Altemir 1973,5,6,16 1974, 1986), pero en todo ese tiempo, creo que pocos han hecho tanto énfasis como quizá ahora nosotros pretendemos, al afirmar con modestia, lo importante que también tienen las venas, en la cirugía de la parótida, descuido que se debe sin duda, a la personalidad anatómica y funcional del nervio facial omnipresente o la obsesión del cirujano por el mismo y cómo no a las particularidades de un campo quirúrgico excepcional. Podríamos tratar de anunciar ahora mismo un axioma que se nos ocurre, de "cómo la correcta cirugía venosa, define no pocas veces un buen hacer quirúrgico".

Es este sentido, el que queremos trasladar a la cirugía parotídea, sin olvidar como no, a la de la glándula submaxilar, de la que ya pretendimos hacer quizá también un manifiesto venoso, en, Hernández Altemir 198511,12, 16,17 y 1986 respectivamente, apuntando algo al respecto, ya el arterial lo había hecho (Yoav P. Talmi 2003) ${ }^{13}$ con fines microquirúrgicos y antes otros, como (Yoel J 1986), ${ }^{14}$ conservando la arteria facial, en la submaxilectomía convencional, para evitar con exquisitez casi extrema, cierto hundimiento de la región submaxilar cuando se secciona y liga, en su caso. Este mismo autor en excelentes esquemas describe el Triangulo de R. Finochietto ${ }^{14} \mathrm{y}$ del mismo J. Yoel ${ }^{14}$ (que nosotros nos atrevemos a llamar el triángulo de la incertidumbre) pese a la existencia de la famosa maniobra de Hayes Martin, ${ }^{9}$ para arrastrar con la vena facial, el ramo marginal fuera del campo quirúrgico y tratar de evitar su lesión en las innumerables cirugías de la zona, donde siempre esta comprometida su continuidad pese a la aludida maniobra. nal jugular, connecting intraparotid and facial vein), understood like this when considering the decubitus of the patient and the lateralization of the surgical field. Which we can see in the iconography (Figs. 1 to 9) of the attached clinical case, especially in figure 6.

Garland, which is formed by the high cervical portion of the external jugular vein, the connecting referred to $s$ the facial vein. Both just below the medial portion of the unstable cervico margin facial branches where a more anatomical designs, morphology, stability are almost always missing, that suspends and swings and at the same time divides. Its peripheral path in the anterior functional part to the blue vein axle that takes the nosogenic enigmatic valley where we want to lose with every surgical intention knowing that they come from another posterior region that is inert and a functional. From a peripheral birth point of view, it is a little bit more than the cervicomastoid vertex of the digastrics, in other words when the trunk is divided into different branches.

We are going to diffuse this poisonous concept, that in our surgical experience gland pathology surgeries with the intention of increasing recognition, path, dissection, conservation and perhaps the nerves possible lesions They involved harm not only functionally evident but the ones that can justify how we conclude that psychosomatic aftereffects that all surgeons in this area are know are many times unpredictable and are an indubitable help to correct excision of the pathology attached to the parotid.

The neck surgeon is mainly a vein fascia surgeon. It is known that he practices from ${ }^{8}$ Crile, 1905, 9 Hayes Martin 1951, ${ }^{10}$ Oswaldo Suarez 1963,5,6,16 Hernandez Altemir 1973, $1974,1986)$ but in all this time, very few have emphasized how we now know the importance that the veins have in the parotid surgery. Not caring for them is credited to the anatomic and functional personality of the facial nerve that is omnipresent and the obsession that the surgeon has with 
La propia maniobra de H. Martín, 9 todos los cirujanos de cabeza y cuello, la hacemos y no pocas veces les decimos a nuestros residentes: "Esta maniobra nos ayuda a separar y con ello proteger al ramo marginal del facial", lo que no deja de ser una verdad a medias y así, de una a otra generación de cirujanos.

Para nosotros, la maniobra de H. Martin, 9 "ya ha cumplido su misión" y en general debe seguir haciéndose cuando venga a mano, dándole su justo valor de salvaguarda de sobre todo del ramo marginal del facial, recordarse pues, insistimos como algo que permanece y es útil, pero que puede ocultar si su realización se hace de forma más o menos sistemática no poco grado de agresividad al interrumpir la continuidad de la arteria y vena faciales, escondiendo pues, puntos de cierta inhabilidad y miedos y encima y para nada, es la salvaguarda absoluta del ramo marginal.

Todos descansamos cuando en la cirugía sobre todo oncológica del cuello, ya hemos controlado arriba y abajo, en la radical y en su longitud en la funcional y no entro en detalles anatómicos, la yugular interna, un poco de lo mismo, es lo que venimos haciendo con las venas parotí-

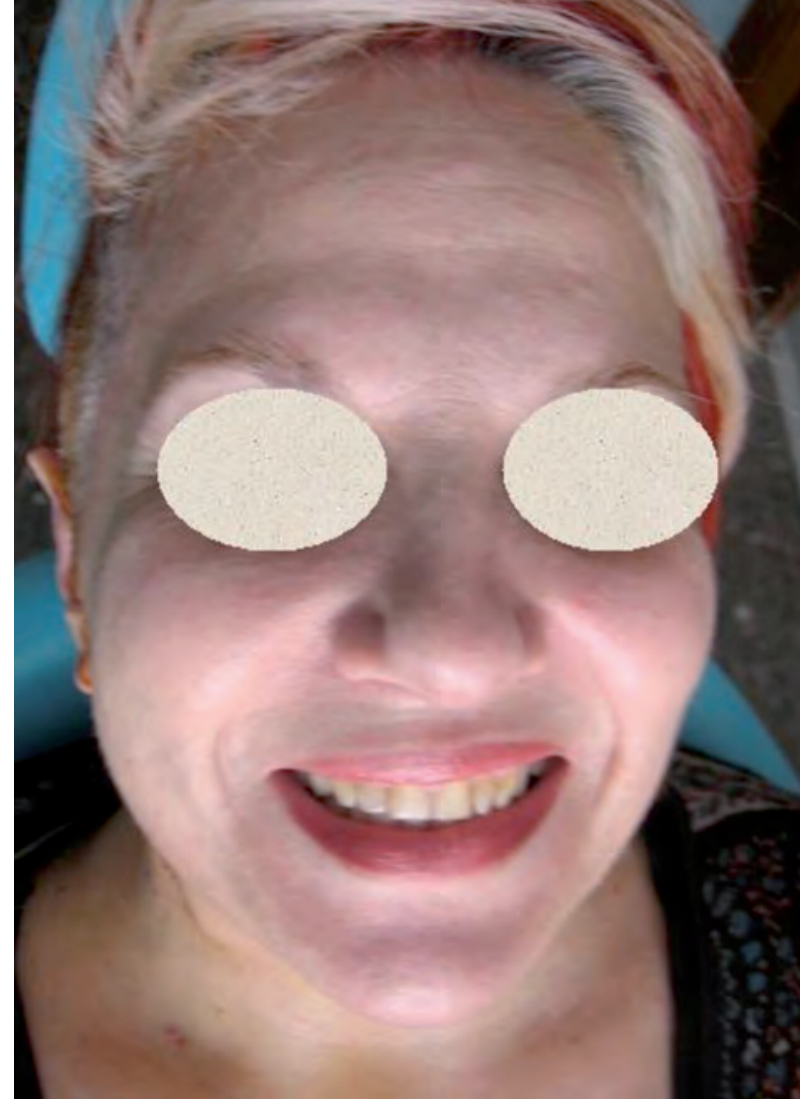

Figura 9. Postoperatorio a los 10 días. Figure 9. 10 days after surgery. deas que nos ayudan a dominar el campo.

Insistimos pues, en revindicar al sistema venoso (ya pilar clásico de la cirugía cervicofacial cómo hemos comentado y que de su correcto trato, se van a determinar cumplimientos quirúrgicos indiscutibles, otorgándole un puesto incuestionable en la práctica que nos ocupa, no sólo por que su control determinara óptimos resultados en la realización de la técnica quirúrgica, sino que le queremos pedir, que sea además, parte fundamental de la anatomía quirúrgica convencional y quitarle el San Benito, de que las venas por su pretendida falta de contundencia anatomofisiológica (suplida fácilmente por colaterales), traducida además en cierta inconstancia, fragilidad quirúrgica y variabilidad (Buarque Gusmáo y col. 2006) $)^{15}$ hay que quitárselas de en medio cuanto antes, para avanzar por campos considerados más definidos y seguros.

Nuestra misión insisto, es reivindicativa de las venas en general y de las de la región parotídea en particular y considerarlas como apoyo de la cirugía, no como inconveniente.

Un matiz del trato de las venas, es que el cirujano habitualmente las liga casi indiscriminadamente y o las quema (electrocoagula), como si fueran herejes, en cambio a las arterias, se les da trato de favor, raramente las quemamos, ligándolas sólo si tienen calibres despreciables, por razones obvias y porque claro, son más funcionales, selectivas y más fácilmente reconocibles y seguibles.

La vena facial y su comunicante intraparotídea, la vena facial posterior, es una vena de entidad, que va a encontrar la rama cervical del facial dentro del tejido parotídeo, cómo muy bien se obser- the particularities of the exceptional surgical field. We could try to announce an axiom "correct vein surgery is very often determined by the good work of the surgeon".

In this sense what we want to transmit to the operated parotid, we don't want to forget that the sub maxilla gland, that we already tried to do, is also a vein manifestation in 1,12,16,17 Hernandez Altemir 1985 and 1986. The artery was already done ${ }^{13}$ (Yoav P. Talmi 2003) with microsurgical ends like (Yoel J 1986), conserving the facial artery in the conventional submaxillectomy to avoid certain sinking of the sub maxilla region when it is sectioned and attached. This same author describes, in excellent conditions, the ${ }^{14}$ Triangle of $R$. Finochietto and of the ${ }^{14}$ J. Yoel (that we tried to call the triangle of doubt) although the existence of the famous work by Hayes Martin, ${ }^{9}$ to carry along with the facial vein, the marginal vein outside the surgical camp and try to avoid its lesion during the numerous surgeries in this zone, where there its continuity is always compromised despite the already mentioned technique.

All head and neck surgeons perform the work by H. Martin; ${ }^{9}$ we do it and often say to our residents: "This technique helps us separate and protect the facial marginal branch" which makes way for a new generation of surgeons.

For us the H. Martin technique has already completed its task an it should generally continue to do it when it comes in handy. Giving it just the safeguard value that above all the marginal facial vein. We insist that it remain useful but it can hidden if its performance is carried out more or less systematically with highly aggressive levels when interrupting the continuity of the artery and facial veins, hiding certain inabilities and ways and for no good reason, it is the absolute safeguard of the marginal branch.

All of us can rest when during surgery, especially a neck surgery, when we have the top, bottom and internal jugular controlled because that is what we tried to do with the parotid glands that helped us dominate the field.

We insist on revindicating the vein system. The classic cervicofacial surgery will have determined indisputable objectives, granting it a place in our practice. Not only because 
va en preparaciones anatómicas coloreadas o no Gil Caicedo, ${ }^{4} 1992$ y que requiere un reconocimiento y no sólo, el ser ligada y traccionada, empleándola como rastrillo hacia cervical del facial caudal como más arriba señalábamos, considerémosla más, conservándola y veremos que es de mas ayuda de lo que habitualmente se le concede.

No pocas veces la disección de las venas aludidas y el reconocimiento del ramo cervical del facial, han sido y pueden seguir siendo movimientos de disección no sólo para el descubrimiento del tronco del facial, sino para la conservación, exposición y seguimiento del ramo marginal, sin duda el coco, de la cirugía más habitual de la cabeza y cuello.

Y todo esto, es decir, reconocer la vena facial, su desarrollo longitudinal supramaseterino, para hacerse luego algo serpenteante, sobrepasado el borde anterior del masetero y progresando en algunas ramas, en la que nos atrevemos a denominar sabana venosa facial supra y premaseterina.

Donde también sobresale de forma muy manifiesta la vena facial, es en su porción mas caudal, submandibular maseterina y ya hemos comentado su indudable perceptibilidad premaseterina, hasta la porción caudal del malar, en conjunto el mayor componente venoso subparotídeo, de la probablemente una de las zonas anatómicas más hermosas y complejas del organismo, donde confluyen estructuras de gran riqueza cromática (se ha dicho más o menos, que la cirugía de la parótida, es el reconocimiento de las distintas estructuras diferenciadas por una sinfonía de colores y sobre todo antes, si no, nos pasábamos, con la perfusión del azul de metileno en los principales conductos y acinos glandulares.

No debemos olvidar sobre todo después de lo que venimos diciendo, que es en la porción caudal del nervio facial, donde aparcan las ramas más determinantes y vulnerables de la cirugía de la parótida y por tanto de los aspectos fundamentales de la expresividad facial o lo que es lo mismo, en la porción infraparotídea del lóbulo superficial, donde esas ramas caudales, en su porción más anterior, se sumergen en la profundidad cómo decíamos, para inervar la musculatura más sensible de la mímica facial peribucal. Sería como, si el facial en su salida y en su trayecto supramuscular fuera como antes adelantábamos "afuncional", para recuperarse en este sentido anterior, cuando se esconde y hunde en cascada, inmediatamente por debajo del surco nasogeniano, para hacerse extraordinariamente activo.

Reconoceremos en nuestro empeño quirúrgico desde el principio y casi en primer lugar el nervio auricular mayor (que intentaremos respetar y seguir hasta donde la patología nos permita), lo mismo que la yugular externa, la comunicante intraparotídea y la vena facial y las dejaremos ampliamente disecadas a plano y nos sorprenderán al ver que las ramas caudales del nervio facial se apoyan en ellas, lo que facilitará su control y seguimiento y nuestro bienestar quirúrgico y todo en beneficio entre otros de obviar con estos intentos conservadores el síndrome de Frey L 1923,19 Hernández Altemir 1985,11,12 1986 y Sánchez Cuellar 2008.20

Para nosotros es pues, la puesta a plano y conservación de las estructuras vasculovenosas caudales a la parótida, un punto clave que queríamos recuperar de la cirugía parotídea. its control provides optimal results but also because we want to ask that it is part of the conventional anatomic surgery and get rid of the idea that veins should be removed as soon as possible because of their fragility and variability.

Our mission is to revindicate the veins, particularly the ones in the parotid region. We consider them surgical support not inconveniences.

The matrix of vein treatment is what the surgeon usually attaches and he burns them. As if they were heretical, but the arteries are rarely burned, and they are attached only if they have decreasing calibers, for obvious reasons and because they are more functional, selective and easier to recognize and follow.

The facial vein and its connective intraparotid, the posterior facial vein, has an entity that can find the cervical branch of the face within the parotid tissue. As we see very well in the anatomic preparations described by Gil Caicedo, 1992 and that require recognition and when attached and tractioned using a rake towards the facial cervical as we talked about prior. We conserve it to see what is more helpful that what normally concedes.

Vein dissection and recognition of the cervical facial branch have been and can continue to be dissection movements not only to discover the facial trunk, but also to conserve and expose the marginal branch. Without a doubt it is the brain of the most common head and neck surgeon.

All of this includes recognizing the facial vein, its suprameseter longitude development, passing over the anterior border of the master and continuing along some branches, where we dare to dominate the facial vein sheet.

The facial vein is more caudal, sub mandible maseter and we have already commented on its indubitable pre maseter perceptibility. Until the caudal portion of the molar along with the major sub parotid vein, probably of the most beautiful and complex anatomic zones where structures of great chromatic richness( it has been said that the parotid surgery is recognized in distinct structures that are recognized by a symphony of colors. If not we went overboard with the perfusion of the blue methylene at the beginning of our conduct and acini glandules.

We need not forget about everything after what we have said. The Caudal portion of the facial nerve where the most determinant and vulnerable facial nerves of the parotid surgery are as well as the fundamental aspects of facial expressiveness or what is the same. In the infra parotid portion of the superficial lobe where these caudal branches are, in its most anterior portion they submerge in the depth. In order to innervar the most sensitive muscle of the peribuccal faces. It would be as if the exit of the facial was like it was before, when we went on "functional" to recover. When they hide and sink in cascade immediately under the nosogenic groove to make it extraordinarily active.

We acknowledge our surgical effort from the beginning and in the first place the main auricular nerve (that we will try to respect and follow where the pathology allows us), the 


\section{Discusión}

Es evidente que en nuestro trabajo no introducimos cambios básicos de lo que clásicamente viene siendo la cirugía de los tumores y patología benigna de la parótida, pero si parece reseñable, que nosotros no hemos sido capaces de ver en las publicaciones de la cirugía de la parótida, que se haga quizá tanto énfasis como nosotros apuntamos en el tratamiento más cuidadoso y conservador del sistema venoso de la región que contemplamos en este trabajo y no por intereses puramente anatómicos y de posible destreza quirúrgica, sino por ayudar con más seguridad al control de la integridad funcional del nervio facial y porque no, del nervio auricular mayor, cuya disección al inicio e la cirugía de la parótida, nos entrena en nuestra ambición quirúrgica conservadora.

\section{Conclusiones}

Creemos que se habrá entendido pues, nuestra intención de hacer a la vena facial, un poco más protagonista en el papel, de lo que ya lo es verdaderamente, en la intimidad e intensidad quirúrgica y porque no siempre emocional de la cirugía parotídea y quizá merecía éste homenaje público.

No debemos entender por ahora, que la cirugía de la parótida pueda ser habitual realizarla con procedimientos endoscópicos, que nos aparten de lo todavía clásicamente establecido (MU.KUAN CHEN 2007). ${ }^{18}$

La cirugía de la parótida siempre es un reto y llegar a ella con humildad activa, un derecho indudable, con el que se debe premiar a nuestros pacientes y a nosotros mismos, por el reto que su realización siempre significa.

\section{Bibliografía}

1. Conley JJ. Tumors of the parotid gland. Surg Clin North Am 1961;51:5.

2. Conley JJ. Techniques of extratemporal facial nerve surgery. En: Surgery of the facial nerve. Ed. Urban Schwarzenberg y W.B. Saunders Co. Philadelphia (USA), 1973.

3. Redón H, Duhamel B, Ginestet G, Frezieres H, Dupuis A, Pons J. Chirurgie des glandes salivares. En: Patel J, Leger L. Nouveau traité de technique chirurgicale, $t$. I. Tete et cou, Ed. Masson et Cie. Paris 1972.

4. Gil-Carcedo LM. Abordaje de los tumores de la parótida. Capítulo XVI Pags. 261274 del libro. El abordaje en el Tratamiento Quirúrgico de los Tumores de Cabeza y Cuello. Ponencia Oficial para 1992 de la Sociedad Española de ORL y Patología Cérvico-Facial.

5. Hernández Altemir F, Castillo Escandon R. Disección radical de cuello (Una modificación en su técnica). NM Especial Domingo 1973;1:5-10.

6. Hernandez Altemir F, Castillo Escandon R. Una modificación en la técnica de McFee para la disección radical simple de cuello. NM Especial Domingo 1974;21-5.

7. Barry'O Regan, Girish Bharadwaj, Andrew Elders. Techniques for dissection of the facial nerve in benign parotid surgery: a cross specialty survey of oral and maxillofacial and ear nose and throat surgeons in the UK. Br j Oral Maxillofac Surg 2008; 46:564-6.

8. Crile GW. On the surgical treatment of cancer of the head and neck. With a summary of one hundred and twenty -one operations performed upon one hundred and five patients. Trans South Surg Gynecol Assoc 1905;18:108-27. same as the external jugular, the connecting intraparotid and the facial vein. We leave them amply dissected and it surprises us to see that the caudal branches of the facial nerve are supported by them. This makes their control and follow up easier and our surgical well being in all of its benefits. Among other obvious conservative attempts with the Frey L syndrome, 1923,11,12 Hernandez Altemir, 1985, 1986 and $^{20}$ Sanchez Cuellar, 2008.

For us it is important to conserve the vasculoveinous caudal structures of the parotid, a key point that we want to recuperate from the parotid surgery.

\section{Discussion}

It is obvious that in our study we don't incorporate basic changes to what has classically been tumor and parotid benign pathology surgery. But it does seem depict able that we have been able to see in parotid surgery publications that they emphasize how we carefully and conservatively note the vein system of the region that is contemplated for this work. Not because of purely anatomic reasons and the possible surgical action, but rather to help by providing more security when controlling the working integrity of the facial nerve and also the large auricular nerve whose initial dissection and parotid surgery keeps us entertained in our conservative surgical ambition.

\section{Conclusions}

In our opinion it has been understood that our intention when making a facial vein, a little more protagonist in role, that what is really, in surgical intensity and because there is not always emotion of the parotid surgeon and perhaps it deserves this public tribute.

We should not think for now that the parotid surgery could be carried out with endoscopic procedures that separate us from what has been classically established.

Parotid surgery is always a challenge and to reach it with humility, activates an indubitable right with which we should give our patients and ourselves because of the challenge and its achievement is quite significant. 
9. Martín Heyes, Del Valle B, Ehrlich H, Cahan WG. Neck dissection. Cancer 1951;4:441-99.

10. Suárez O. El problema de las metástasis linfáticas y alejadas del cancer de hipofaringe. Rev Otorrinolaringol, Santiago, 1963;23:83-99.

11. Hernández Altemir F. Una modificación técnica de la submaxilectomía cervical. Revista Iberoamericana de Cirugía Oral y Maxilofacial 1985;7:223-6.

12. Hernández Altemir F, Alonso del Hoyo JR. President of the European Association for Maxillo Facial Surgery and of the 8th Congress of the E.A.M.F.S., Certifies Herewith that Dr. Francisco Hernández Altemir has presented at the Congress the following paper. A technical modification of the cervical submaxilectomy $8^{\text {th }}$ - Congress E.A.M.F.S. Madrid $15^{\text {th-19th }}$ September 1986.

13. Yoav Talmi P, Wolf M, Bedrin L, Horowitz Z, Dori S, Chaushu G, Yahalom $\mathrm{R}$, Taicher $\mathrm{S}$, Kronenberg J. Preservation of the facial artery in excision of the submandibular salivary gland. Br J Plast Surg 2003;56:1567.
14. Yoel J. Atlas de Cirugía de Cabeza y Cuello. Salvat 1986.

15. Buarque Gusmäo LC, de Sousa-Rodrígues F, González de Nobrega FS, Teixeira Pereira da Silva LM. Drenaje de las venas Facial, Lingual y Tiroidea Superior en el Hombre. Int J Morphol 2006;24:685-8.

16. Hernández Altemir F. Una Modificación en la técnica de la disección radical simple de cuello. Rev Eberoamer Cirg Oral y Maxilof 1986;8: 1316.

17. Hernández Altemir F. Pericraneal Fixation of the Nasotracheal Tube. J Oral Maxillofac Surg 1986;44:585.

18. Mu-Kuan Chen MD MS PhD, Cheng-Chuan Chang MD. Minimally Invasive Endoscope-Assisted Parotidectomy: A New Approach. The Laryngoscope 2007;117:(1934-37).

19. Frey L. Le síndrome du nerf auriculotemporal. Rev Neurol 1923;2: 97.

20. Sánchez Cuellar LA. Application of botulin toxin a for the treatment of Frey's Syndrome. Rev Esp Cirug Oral y Maxilofac 2008;30 Madrid. 